\title{
O IZVORIMA SLANE VODE KOD STUBICE I SLANJA PREMA ARHIVSKIM PODACIMA I TERENSKOM ISTRAŽIVANJU
}

Rad donosi nove podatke iz arhivske dokumentacije važne za razumijevanje izvora slane vode kod Slanog potoka (kraj Stubice) i dva izvora slane vode sela Slanje (kraj Varaždinskih Toplica). Kako je sol od uvijek do danas imala važnu ulogu u prehrani ljudi i životinja te u raznim epohama razvoja ljudske civilizacije, osigurala je velik utjecaj u raznim kulturama diljem svijeta. Podaci u radu imaju osnovni cilj pridonijeti boljem poznavanju zaboravljenih izvora slane vode Slanja. U kronološkom slijedu dan je presjek događaja koji su vezani uz istraživanje izvora vode kraj Slanja tzv. Slanca, a prikazuju se po prvi puta i povijesno vrijedne skice navedenih lokaliteta koje je izradio Alojz Rikard Schmiedt (1804.-1899.).

Tijekom provedenog istraživanja 2018., kada je otkrivena navedena arhivska dokumentacija u Hrvatskom državnom arhivu u Zagrebu, ista je bila temelj, ali i poticaj za nova terenska istraživanja na lokalitetu Slanje. S obzirom da su vremenom navedeni izvori vode pali u zaborav i sada se nalaze u zapuštenom stanju, ovaj rad ima također cilj skrenuti pozornost stručnjaka na njihovu vrijednost i važnost u potrebi izrade nove interpretacije, valorizacije i popularizacije kao posebne grane geološke baštine Republike Hrvatske. U radu se donose i ostali vrijedni povijesni podaci za navedeno područje, ali i druge nove znanstvene spoznaje do kojih se istraživanjem došlo.

Ključne riječi: geologija; balneologija; arheologija; izvori slane vode; kamenita sol. 
SPOMENKA VLAHOVIĆ : O izvorima slane vode kod Stubice i Slanja prema arhivskim podacima...

\section{SLANCI - IZVORI SLANE VODE I SELO SLANJE NEDALEKO VARAŽDINSKIH TOPLICA}

Vrijedno arhivsko gradivo otkriveno 2018. u Hrvatskom državnom arhivu u Zagrebu govori o istraživanju izvora slane vode tzv. slancah kod sela Slanje nedaleko Varaždinskih Toplica. Otkrivena povijesna građa predstavlja važan izvor raznih informacija, kao i rijedak slikovni prikaz tj. skicu položaja spomenutih izvora slane vode (slika 1. i 6.) ${ }^{1}$ Geološki lokalitet smješten je na području Varaždinske županije, u općini Martijanec, a predstavlja vrijednu očuvanu i nadasve zanimljivu povijesno - geološku kontinentalnu baštinu.

Povijesni pregled razvoja posjeda Slanje istražio je dr. sc. Hrvoje Petrić koji kaže "... naziv Slanje odgovara današnjem istoimenom naselju smještenom uz dolinu rijeke Bednje između Varaždinsko-topličkog i Kalničkog gorja. Slanje se kao posjed spominje od 1248. godine, a samostalni posjed se spominje i kasnije npr. oko $1450 .{ }^{2}$...". Detaljne povijesne podatke između ostalih donosi istraživač Antun Kancijan 1985. kad daje zanimljive povijesne podatke o značenju samog toponima Slanje u kojem nazire pradavne Slavenske korijene. Stari naziv sela bio je Zlowna (Slovna), a po prvi puta se pod nazivom Slanje spominje 1248. godine. Poslije pet godina, točnije 1253. koristi se naziv Zlayna (Slajna). Otkriveni su i ovi nazivi: Zlauina (Slavina) godine 1334., Zlayno (Slajno) 1495., Zlanya (Slanja) 1507., Zlayno (Slajno) 1598., Zlanno (Slano) 1600., Zlania (Slanja) 1671., Szlanio (Slanjo) 1680. i Szlanye (Slanje) 1771. godine. Kancijan spominje tezu po kojoj je Slanje dobilo naziv prema slanom izvoru vode koji se nalazi u njegovoj blizini, međutim on smatra da je stupanj saliniteta vode vrlo nizak, te nije opravdano mišljenje da je selo na temelju toga dobilo naziv.

S obzirom da se o samom lokalitetu izvora slane vode tzv. Slancah do sada u stručnoj literaturi nije puno pisalo, cilj je ovog članka predstavit zanimljivu povijesnu i jedinstvenu geološku lokaciju izvora vode kod sela Slanje, ali i prikazati nove rezultate provedenog arhivskog i terenskog istraživanja provedenog osim u Zagrebu i u Zavičajnom muzeju Varaždinske Toplice i na položaju današnjeg sela Slanje nedaleko Varaždinskih Toplica.

1 Hrvatski državni arhiv u Zagrebu, HR-HDA-79, svezak 20, 10853/1870, kutija 38, „Skizze über die Lage der Salzquellen bei Slanje in Croatien“.

2 Hrvoje PETRIĆ, „O nekim naseljima u porječju rijeke Bednje tijekom srednjeg i početkom novog vijeka", u časopis KAJ, XLIII, br. 3., Zagreb, 2010., str. 103.

3 Antun KANCIJAN, Traganje za podrijetlom imena sela ludbreške Podravine (2), u: Podravski zbornik, No. 10., tisak SOUR Podravka, Koprivnička tiskara, nakladnik Muzej Grada Koprivnice, 1984., str. 246-256. 


\section{KRONOLOŠKI PREGLED AUTORA S PRVIM PODACIMA O SELU SLANJE I IZVORIMA SLANE VODE}

Austrijski istraživač Franz Raffelsperger je još 1848. donio u općem geografskom leksikonu podatke za selo Slanje gdje navodi da se nalazi u sastavu Križevačke županije, na teritoriju Podravine, gdje je nekada bilo gospodarstvo plemićke obitelji Lendvay s tvrđavom, majurom, mlinom i gostionicom. Prema istom izvoru navedeno selo broji 69 kuća i 416 stanovnika koji pripadaju župi Martijanec. Selo se nalazi na toku rijeke Bednje i udaljeno je oko 1 sat hoda od Ludbrega. ${ }^{4}$ Od hrvatskih istraživača prve informacije donosi Ludovico Farkaš Vukotinović 1852. u geognostičkoj skici u kojoj piše da se istočno od Varaždinskih Toplica udaljenih 1 sat hoda nalazi selo Slanje i zanimljiv izvor slane vode koja još nije kemijski istraživena. ${ }^{5}$ Isti autor 1869 . donosi zanimljive podatke za bogatu bioraznolikost sela Slanje s okolicom u tekstu "Flora croatica ${ }^{\prime 6}{ }^{6}$ Njemački stručnjak Otto Hübner 1853. donosi prve vijesti za provedena površinska ispitivanja soli u Slanju i Apatovcu u Kalničkom gorju i navodi da su dala rezultate o postojanju soli. Isti u izvještaju traži da radovi ispitivanja soli na navedenim lokalitetima u budućnosti budu nastavljeni, a tekst zaključuje tvrdnjom da su izvori kod Slanog potoka, Slanja i Apatovca korišteni samo za potrebe lokalnog stanovništva.' Živko Vasić 1868. u objavljenom geografskom tekstu konstatira kako slane vode na našim prostorima ima u Jadranskom moru, Vranskom jezeru, Slanom potoku kod Stubičkih Toplica, potočiću Slanje i vrelu Slankamenskom. ${ }^{8}$ I ovaj autor navodi

Franz RAFFELSPERGER, Allgemeines geographisches - statististisches Lexikon aller Österreichisc-

${ }^{4}$ hen Staaten 5 svezak, 2 izdanje, Wien 1848., https://books.google.hr

Ludovico Farkaš VUKOTINOVIĆ, Geognostische Skizze vom Warasdiner Toplitz in Croatien, u: Ja-

hrbuch der Geologischen Reichsanstalt 3/4, Wien, 1852., str. 13.

Isto, www.biodiversitylibrary.org

6 Otto HÜBNER, Nachrichten aus dem Gebiete Staats- und Volkswirtschaft nebst Beilage Versiche-

rungs-Zeitung, 2. svezak, Brandis, Berlin 1853., str. 125., https://books.google.hr

Lokalitet Slankamen nalazi se u Vojvodini, izvor ljekovite mineralne vode naziva se "Slanače“.

Temperatura vode iznosi $18,4^{\circ} \mathrm{C}$, slana voda sadrži ljekovite elemente poput natrijum-klorida, joda, magnezija, kalcija, stroncija i barija. Tradicija korištenja vode datira još u rimski period. Arheolozi su potvrdili ostatke antičkog naselja Acumincuma što u prijevodu znači „,mjesto na brdu“. U blizini izvorišta vode tijekom povijesti Turci su izgradili amam tj. slanu kupelj. Poznato je također, da je slana voda ovog lokaliteta otjecala u rijeku Dunav sve do 1834. kada je austro-ugarska vlast ogradila prirodno izvorište i kaptirala više izvora vode u jedan koji danas napaja kupalište. Treba istaknuti, da se nedaleko izvora slane vode kod Slanja na obližnjem brdu nalazi lokalitet Gradecz koji do sada nije istraživan, a mogao bi dati važne podatke za period antike, možda i izvore slane vode s obzirom da je u blizini ruta antičke ceste koja je vodila od Aquae lasae (Varaždinske Toplice) u loviu (Ludbreg). Potencijalno arheološko nalazište smješteno na brdu možda je i starije, a potječe vjerojatno iz doba prapovijesti. Na karti koja se nalazi u Zavičajnom muzeju 
kod Slanja blizu Varaždinskih Toplica nije ništa poznato. ${ }^{9} U$ tekstu se navodi da su se upravo takve vode tzv. vode - rudnice tijekom povijesti koristile za potrebe „ljekarstva i zemljoznanstva“, a u slučaju Slankamenskog lokaliteta tamošnje žene slanu vodu koristile su za izradu domaćeg kruha kako bi uštedjele soli. Autor navodi kako lokalitet Slanog potoka blizu Stubičkih Toplica ima vodu bistru, bijelu i malo zelenkastu i slanu, te da 1 funta ili 7680 grama te vode ima ukupno 122 grama obične soli. Posebna težina joj je 1.05, a temperatura u potoku iznosi $7.50^{\circ} \mathrm{C}^{10}$

Tijekom provedenog istraživanja u Hrvatskom državnom arhivu u Zagrebu pregledana je i veća količina arhivskih dokumenata u potrazi za podacima o lokalitetu slane vode kod sela Slanje i tom prilikom otkrivena je povijesno vrijedna skica Alojza Rikarda Schmiedta, penzioniranog carskog i kraljevskog savjetnika iz 1871. Skica prikazuje ležišta soli sa shematskim prikazom Slanog potoka lokalnog puta za Stubicu s okolnim krajolikom na njemačkom jeziku. Autor Schmiedt ucrtao je vrlo detaljno sve položaje s raznim vrstama kamenja u okolici te označio kružnom oznakom točnu poziciju položaja vađenja soli. Na istoj skici nalazi se zanimljiv prikaz rudarskog okna Slanog Potoka kod Stubice, a detaljno izrađeni autorov presjek nudi promatraču uvid u tadašnje aktualno stanje na terenu $\mathrm{tj}$. pogled u rudarsko okno kao i stanje u geološki presjek terena i navedeno ležište soli.

Varaždinske Toplice položaj Gradecz označen je na vrhu brda od 257 metara i označen toponimom Zrut. Riječ lokalni mještani koriste u govoru kad žele reći da je nešto uništeno tj. „zrutano". Oko 1,5 - 2 km istočno od sela Slanje evidentiran je arheološki lokalitet srednjeg vijeka s nazivom Stari Graci smješten je na sjeveroistočnim podinama Kalničkog gorja iznad nizine rijeke Bednje, (op. a.).

9 Živko VASIĆ, Pabirci za zemljoslovlje Dalmacije, Hrvatske i Slavonije“, Zagreb, 1868., str. 171.

10 Isto. 


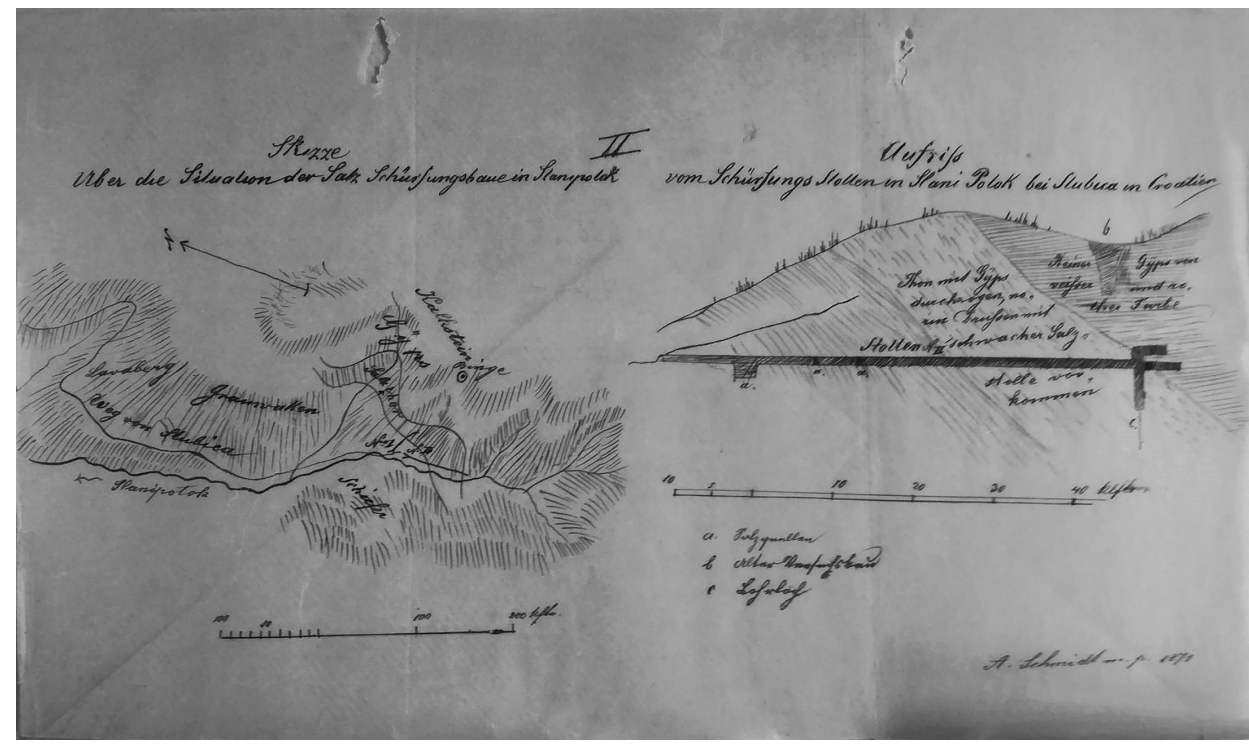

Slika 1. Skica na pausu Alojza Rikarda Schmiedta s položajem ležišta soli kod Slanog potoka s prikazom presjeka lokacije rova Slanog potoka kod Stubice iz 1871., HR-HDA-79; sv. 20., 10853/1870-4174/1871

Naziv lokaliteta izviranja vode Slani Potok potječe od glavne karakteristike vode koja je slano-gorkastog okusa. Povijesni podaci govore kako je sol tj. slana voda bila nekada vađena iz bunara koji se nazivaju „šokoti“, a mještani su ih kao što je poznato koristili uslijed nedostatka soli za kuhanje. Provedena analiza utvrdila je da voda sadrži 1,56 \% otopljenog $\mathrm{NaCl}$ i $21,1 \mathrm{~g} / \mathrm{kg} \mathrm{NaCl}$ - natrijev klorid ili kuhinjsku sol. Smatra se da specifičan gorkasti okus potječe od drugih sastojaka i to od otopljenih soli magnezijevog karbonata, kalcijevog sulfata i magnezijevog sulfata. Stari zapisi o najstarijoj rudarskoj aktivnosti na Medvednici vezani su upravo uz lokalitet Slanog Potoka. Na navedenom položaju još 1347. sol se vadila iz bunara tzv. šokota, no ubrzo je napuštena jer je sol bila slaba. Spomenuti potok izvire u šumi iznad naselja u predjelu zvanom Šokot na 450 metara nadmorske visine. Prvi povijesni dokument koji govori o ležištu soli na Medvednici potječe iz 1347. kada 
ban Nikola dobiva prve vijesti da bi se na tom mjestu mogla pronaći sol. U 18 . stoljeću grof Krsto Oršić pokušao je obnoviti postupak vađenja soli na tom položaju, no nije uspio. Danas se na tom lokalitetu nalazi planinarska staza kao i ostaci ulaza u nekadašnji rudnik koji je napušten i zatrpan. Do sada o samoj veličini i izgledu rudnika nije bilo poznatih podataka. Poznata je samo informacija da je navodno bio smješten u vrlo trošnim glinenim škriljavcima. ${ }^{11}$

Vezano uz ovaj zanimljiv geološki lokalitet Slanog Potoka treba reći kako je Anton Edler von Hartig, službeni kupališni liječnik u Stubici 1820. napisao knjigu na njemačkom jeziku pod naslovom „Physisch-chemische Untersuchung der Mineralquellen von Stubitza in Croatien"koja daje detaljan pregled svih informacija vezanih uz kupalište Stubica kao i metodama liječenja u kupkama, ali daje i pregled kemijske analize ljekovite vode koja se koristi u balneološkom liječenju pacijenata. ${ }^{12} U$ navedenoj balneološkoj literaturi nalaze se i dva vrijedna povijesna prikaza Stubice koje donosimo, jer prikazuju originalne položaje navedenog rudnika i Slanog Potoka. ${ }^{13}$

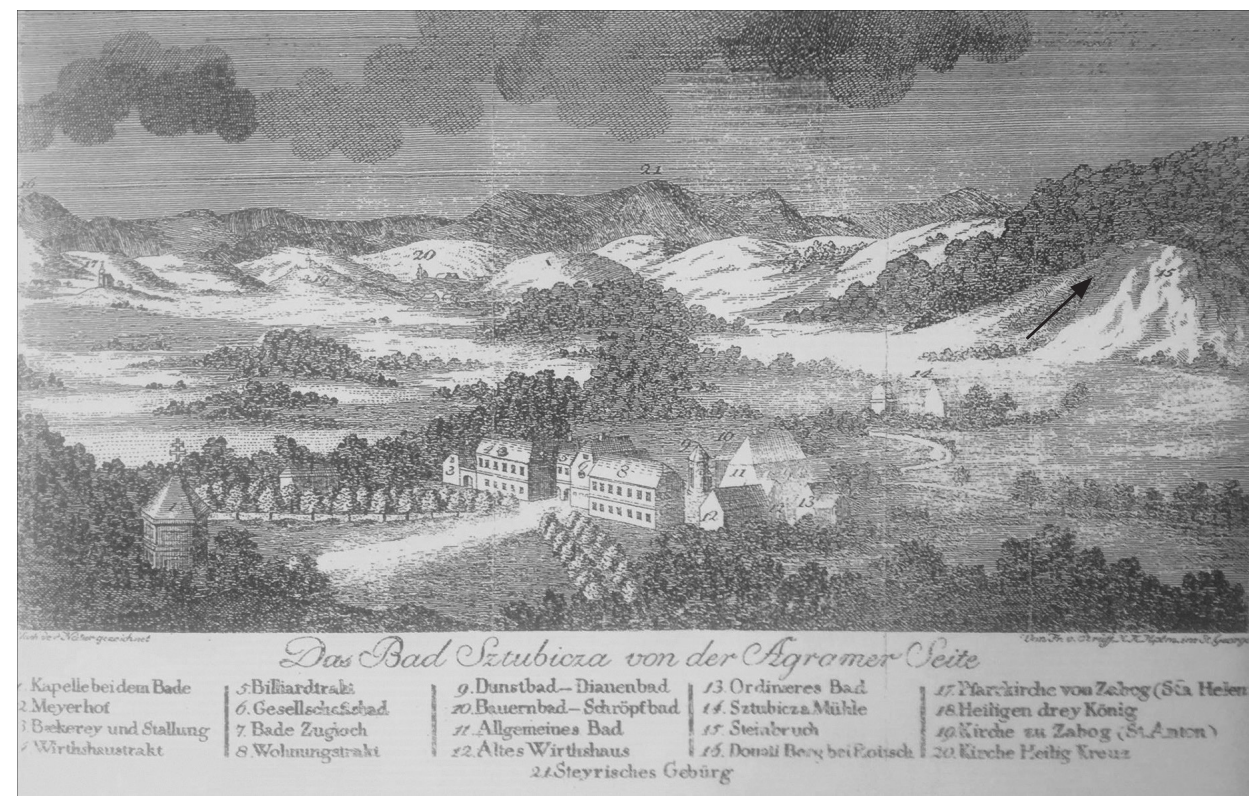

Slika 2. Prikaz Stubice iz 1820. godine. Pod rednim brojem 15 označen je položaj rudnika

11 Podaci preuzeti s web stranice parka Medvednice: pd-zagorske-steze.hr, 11.ožujka 2021.

12 „Fizičko-kemijsko istraživanje mineralnih izvora Stubice u Hrvatskoj", (op. a.).

13 Anton Edler von HARTIG, Physisch-chemische Untersuchung der Mineralquellen von Stubitza in Croatien, Agram 1820. Navedena knjiga čuva se u Zavičajnom muzeju Varaždinske Toplice, inv. br. 119., (op. a.) 


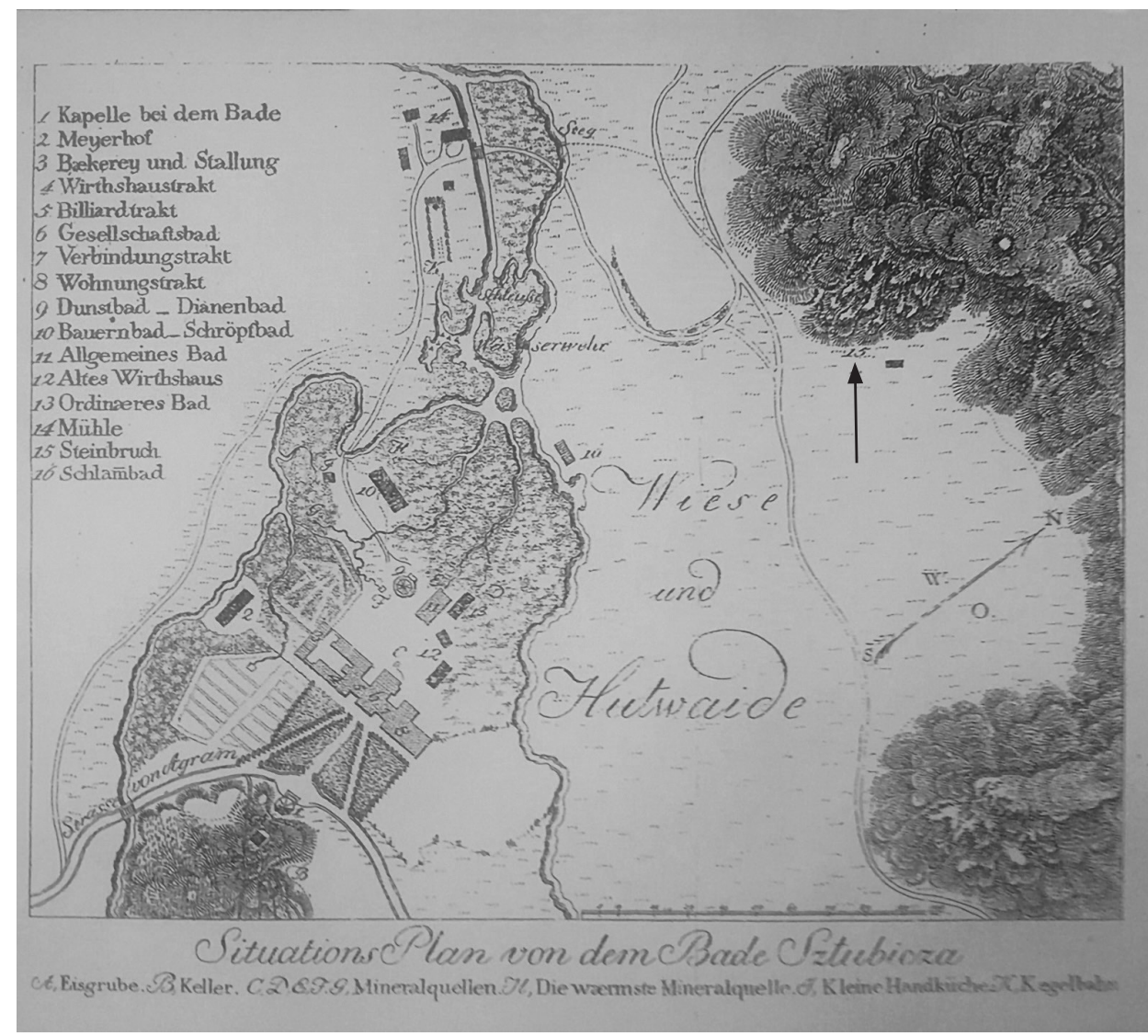

Slika 3. Situacijski plan kupališta Stubice 1820.godine.

Pod rednim brojem 15 označen je rudnik

Vezano uz temu istraživanja izvora slane vode Vjekoslav Klaić u poučnoj knjižici objavljenoj 1878. pod naslovom „Prirodni zemljopis Hrvatske“ govori da se Slanje nalazi u Križevačkoj županiji udaljeno 1 sat hoda od Varaždinskih Toplica, i da je tamošnje vrelo radi slanog teka dobro poznato, no nije ispitano. ${ }^{14} \mathrm{~L}$. W. Berezin

14 Vjekoslav KLAIĆ, Prirodni zemljopis Hrvatske, poučna knjižica, Matica Hrvatska, knjiga 1., Zagreb, 1878., str. 238. 
u tekstu o mineralnim izvorima rijekama i močvarama donosi razne podatke o vodi Varaždinskih Toplica i slanoj vodi Apatovca. ${ }^{15}$

Jedan od najboljih opisa povijesno - geološkog lokaliteta s izvorima slane vode kod Slanja je od Dragutina Hirca koji je nakon što je posjetio područje okolice sela Martijanec napisao „Putne uspomene“ koje je objavio u časopisu „Hrvatski planinar" 1902. godine. Zbog lijepog opisa lokaliteta donosimo dio originalnog teksta koji najbolje ilustrira čitatelju navedeni lokalitet slane vode. „Po imenu zanimalo nas jer i Slanje, a pogotovo onda, kad čitasmo na "Generalstabkarti“ "Salz Quellen“ od kojih je izvora mjesto dobilo i ime. Pošli smo 8. kolovoza po podne i za po sata bijasmo u mjestu, koje se iztiče svojim dvorom grofa Lamberta, paromlinom, tvornicom škroba i postolarske dretve. Preko Bednje vodi most do jednog jalšika u kojem zagledasmo oveliki kal u kojem da je voda slana. Kušali smo vodu, ali našli, da nije slana, već lužnata okusa, jer kalu pritiče iz šume jedan potočić sladke vode. Pravo vrelo leži malo podalje u gustom hladu. Tu je izkopan bunar, dubok $1.10 \mathrm{~m}$ i ogradjen deblom od hrasta, a odtiče iz njega potočak dug 10 - $12 \mathrm{~m}$, što pritiče onomu drugom potočiću. Stali smo i gledali u vodu i vidjeli kako se dižu iz dna veći i manji mjehuri, koji se na površini vode razpucaju. Kadkad se dignu sitniji mjehurići prama površini tako brojni i tako naglo, kao da se razsuo niz bisera. Kušali smo vodu i našli, da je lužnato-slana, a temperatura joj bila u 5 sati $17^{\circ} \mathrm{C}$. Na okolo vrela tlo je pjeskovito, pak kad smo se u nj zagledali, opazismo, da se i iz njega dižu mjehuri. Momak, koji nas je poveo, upali žigicu, pridigne ju brzo k mjehuru, mjehur se upalio i izgorio crvenkasto-žutim plamenom te pucketao, kao što pucketa morska sol, kad ju bacimo u vatru. ${ }^{16}$

15 L. W. BEREZIN, Mineralni izvori i rijeke i močvare, $\mathrm{u}$ „Kroatien, Slavonien, Dalmatien und das Militärgrenzland“, Wien, 1880., str. 15., https://www.dlib.si/stream/urn, 21. veljače 2020. planinarskog društva, br. 11. i 12., mjesec studeni 1902. God. V,. Zagreb, str. 88. 


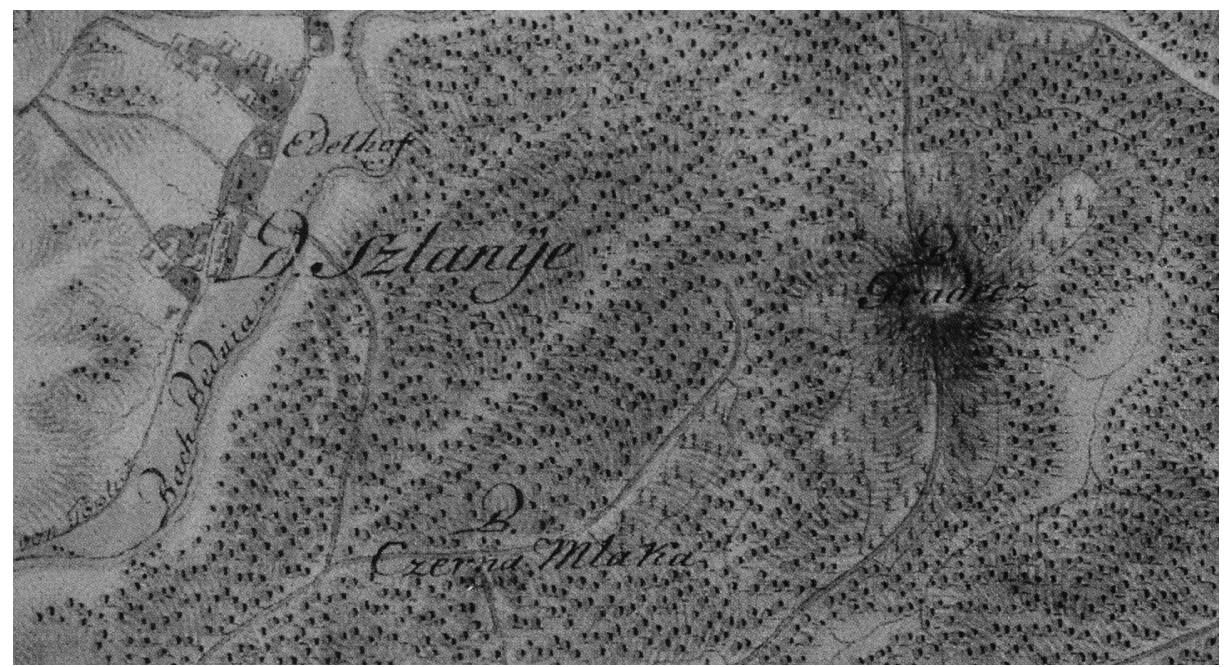

Slika 4. Detalj povijesne karte dijela Varaždinske i Križevačke županije s prikazom sela Slanje i rijeke Bednje s lokalitetom Gradecz „Hrvatska na tajnim zemljovidima 18. i 19. stoljeća“

\section{REZULTATI ARHIVSKOG ISTRAŽIVANJA U HRVATSKOM DRŽAVNOM ARHIVU U ZAGREBU 2018. GODINE}

Zahvaljujući provedenom arhivskom istraživanju došlo se do vrlo važne povijesne dokumentacije Zemaljske vlade Odjela za unutarnje poslove (1869-1921). Prilikom proučavanja dokumenata otkriven je zanimljiv povijesni spis s neobjavljenim arhivskim podacima o izvorima slane vode kod sela Slanje kao i položajni nacrt na pausu s prikazom slanih izvora vode Slanja i starog korita rijeke Bednje (slika 6). ${ }^{17}$ Otkriveni podaci govore da je 1868. iz interpelacije u Dnevniku sabora trojedne Kraljevine Dalmacije, Hrvatske i Slavonije iz reagiranja Šandora Barabaša, tadašnjeg narodnog zastupnika kotara Novi Marof, velikog suca i člana Donjeg doma zajedničkog sabora od 1868.-1871., bilo jasno da je na visoku i kraljevsku hrvatsko-slavonsku-dalmatinsku vladu austrijska carska kraljevska vlada slala već tridesetih godina povjerenstva u Slanje koja su istraživala znanstveno slance (Salzquellen) i očitovala se da kamenite soli tamo ima.

17 HR-HDA-79; sv. 20., 10853/1870-4174/1871. 
"Kadno je nagodba izmedju Austrije i Ugarske, zatim izmedju ove i Hrvatske sklopljena, došlo je opet povjerenstvo u Slanje i to g. 1868. koje opetovano očitova, da tamo kamenite soli ima, pa da bi se na sloj kopanjem ili vrtanjem doći moralo i da bi od velike važnosti za Ugarsku i Hrvatsku bilo, kad bi se stvar ozbiljno u ruke poprimila; nu sva ova povjerenstva nisu žalibože dalje ništa učinila. U Slanju županije križevačke kod Varaždinskih Toplica nalaze se dva slanca (slana vriela), imajuća podosta slanosti znanstveno je dokazano, a i kroz praksu je ustanovljeno, da ima svagdje, gdje se slanci nalaze, kamenite soli, stoji dakle, da imade u Slanju sloja (Lager) kamenite soli: da je kod nas ciena kamenitoj soli veća, nego li u svih susjednih pokrajinah i da su dohoci državni prikraćeni kroz to, što se mnogo za kiriju iz Erdelja i Galicije u južne krajeve Ugarske i Hrvatske plaćati mora, konačno jest statistički dokazano i to, da se manje soli u Austriji; Ugarskoj i Hrvatskoj (uslied prevelike naime ciene iste) troši, nego li zahteva ljudsko zdravlje, a koliko manje, nego li potrebuje marva. Iz gore rečenoga proizlazi jasno, da je pomnoženje kamenite soli uz mali trošak za dobivanje iste od prevelike potriebe za nas, a za državu od velike koristi. Pošto ipak ništa dosele u tom važnom predmetu učinjeno nije, usudjujem se kao zastupnik kotara, u kojem te slanice leže upitati visoku kraljevsku hrvatsko-slavonsko-dalmatinsku vladu:

1.) Da li je vis. kr. zemaljskoj vladi o pomenutih slanicah što znano.

2.) Zašto nije pokušano, da se do sloja kamenite soli u Slanjcu dodje.

3.) Je li visoka vlada namjerava te pokuse učiniti, te vrtanje i kopanje sloja preduzeti dati.

U Zagrebu, 29. studenog 1870. “18

Vezano uz gore navedeni zahtjev u predmetu korištenja ležišta soli kod Slanja saznajemo da je na saborskoj sjednici 2. prosinca 1870. zastupnik vlade Robert Zlatorić dao sljedeći odgovor narodnom zastupniku Šandoru Barabošu: „Vis. kućo! Nadalje imam čast odgovoriti na interpelaciju gospodina zastupnika Barabaša, učinjenu u prekjučerašnjoj sjednici u pogledu soli u Slanju u križevačkoj županiji potražene i nadjene. Odgovor moj bit će sasvim kratki, te ću se svrnuti samo na ono, što je zemaljskoj vladi poznato, naime, da su povjerenstva u tom poslu opetovano radila, nego se osvjedočila, da se ova sol ne nalazi u tolikoj množini i čistoći, koja bi potrebita bila, da se izvadjanje rentiralo.

18 „Dnevnik sabora trojedne kraljevine Dalmacije, Hrvatske i Slavonije“, održana u glavnom gradu Zagrebu, godine 1868.-1871., Zagreb, tiskara „Narodnih novinah“, e-knjiga: https://books.goog ogle.hr, str. 1076., 13. siječnja 2020. 
Usljed toga, vlada u tom poslu nije mogla ništa raditi; medjutim će zemaljska vlada polag dužnosti svoje, da u svakom poslu, koji se odnosi na materijalnu korist zemlje, sve mjere upotrebiti, uzamši ovu stvar u svoje zaklonište, obratiti se na zajedničko ministarstvo financijah, na koje i stvar spada, da i ono razvidi, da li je prema mogućnosti, da se ovo vrelo otvori i ovo blago na korist zemlje obrati. Vlada će u sporazumljenju s ugarskim ministarstvom financijah shodne mjere učiniti. Ja molim, da bi se g. interpelant s ovim odgovorom zadovoljiti, i visoka kuća na znanje ga uzeti izvolila; zemaljska vlada će nastojati, da stvar čim prije dovrši.

Šandor Baraboš: Ja se sodgovorom g. zastupnika vlade zadovoljavam. Predsjednik: Prima se na znanje. ${ }^{19}$

Kraljevsko hrvatsko-slavonsko-dalmatinska zemaljska vlada, odjel za unutarnje poslove vezano na pitanje eksploatacije soli iz dva slanca poslala je zatim 1871. predmet na Kraljevsko Rudarsko Satništvo u Zagreb kao i Ministarstvu financija s pitanjem da li bi se eksploatacija soli na navedenom lokalitetu isplatila i kako bi prikupili više podataka. Ministarstvo financija u Zagrebu dalo je pisani dogovor zemaljskoj vladi kako se s navedenim pitanjem znanstveno bavio penzionirani carski i kraljevski savjetnik Alojs Rikard Schmiedt „,... koji je za svojih službenih putovanja sva slanska vrela a i ona u Slanju upoznao - ... rudah u predielu Slanjskom. Občinski savjetnik Šmidt izjavio je u odgovoru na ovaj poziv, da bi se povoljan uspieh u Slanju „postići mogao, kad bi se vrtanjem preduzelo, koje je on još za svoga službovanja u carskom i kraljevskom bečkom ministarstvu predložio, no koje iz razlogah bilo kraljevsko rudarsko satništvo u Zagrebu, da glede toga preduzme ... izvješće ovoj kraljevskoj zemaljskoj vladi podnese. Uslied ovog poziva poduzelo je rečeno kraljevsko rudarsko satništvo 10. svibnja 1871. br. 465 svoje izvješće i priložilo tome ispravke iz zapisnikah postojavšeg u Samoboru, Varaždinu i Radoboju carskom i kraljevskom zemaljskog rudarskog suda radi pismene izjave dva slankovnjaka - koja se izvješća skupa sa ovim prilozi slavnom kraljevskom ministarstvu u privitku".20

\footnotetext{
19 „Dnevnik sabora trojedne kraljevine Dalmacije, Hrvatske i Slavonije“, držana u glavnom gradu Zagrebu, tiskara „Narodnih novinah", str. 1101.,e knjiga: https://books.google.hr, 13. siječnja 2020.

20 Isto.
} 
SPOMENKA VLAHOVIĆ : O izvorima slane vode kod Stubice i Slanja prema arhivskim podacima...

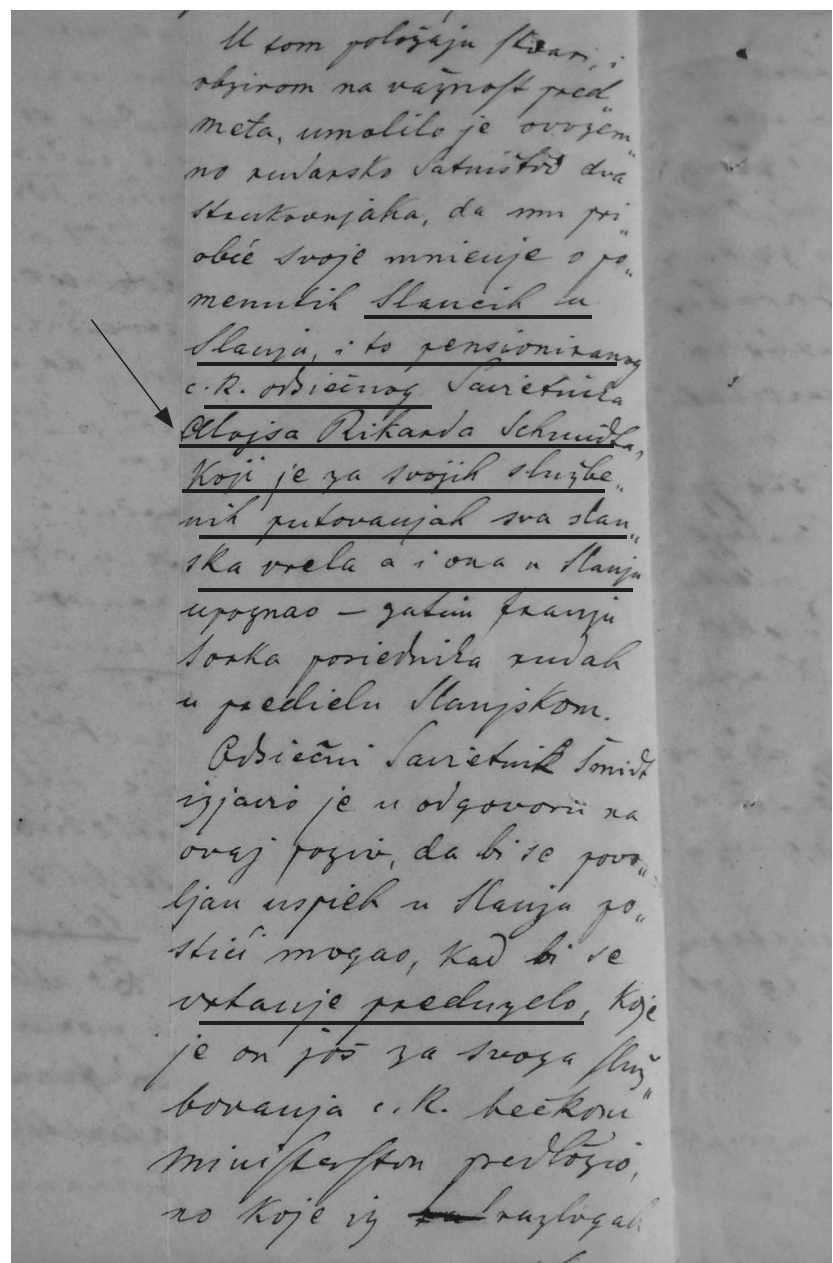

Slika 5. Pogled na 2. stranicu originalnog predmeta upućenog na Kraljevsko-ugarsko Ministarstvo financija u Pešti u vezi interpelacije Šandora Baraboša iz 1871., HR-HDA-79; sv. 20., 10853/1870-4174/1871.

Na temelju otkrivenih povijesnih podataka može se zaključiti kako se radi o povijesno provedenom istraživanju izvora slane vode kod sela Slanje, koje je proveo uz dolinu rijeke Bednje između Varaždinsko-topličkog i Kalničkog gorja poznati penzionirani carski i kraljevski savjetnik 1871. Alojz Rikard Schmiedt. Zbog zanimljivog prikaza povijesnih i geografskih podataka donosimo u cijelosti originalni položajni nacrt s ucrtanim izvorima slane vode. ${ }^{21}$

21 U arhivskom spisu sv. 10853/1870; kutija 38 br. 4174 iz 1871. godine Kraljevsko hrvatsko-sla- 


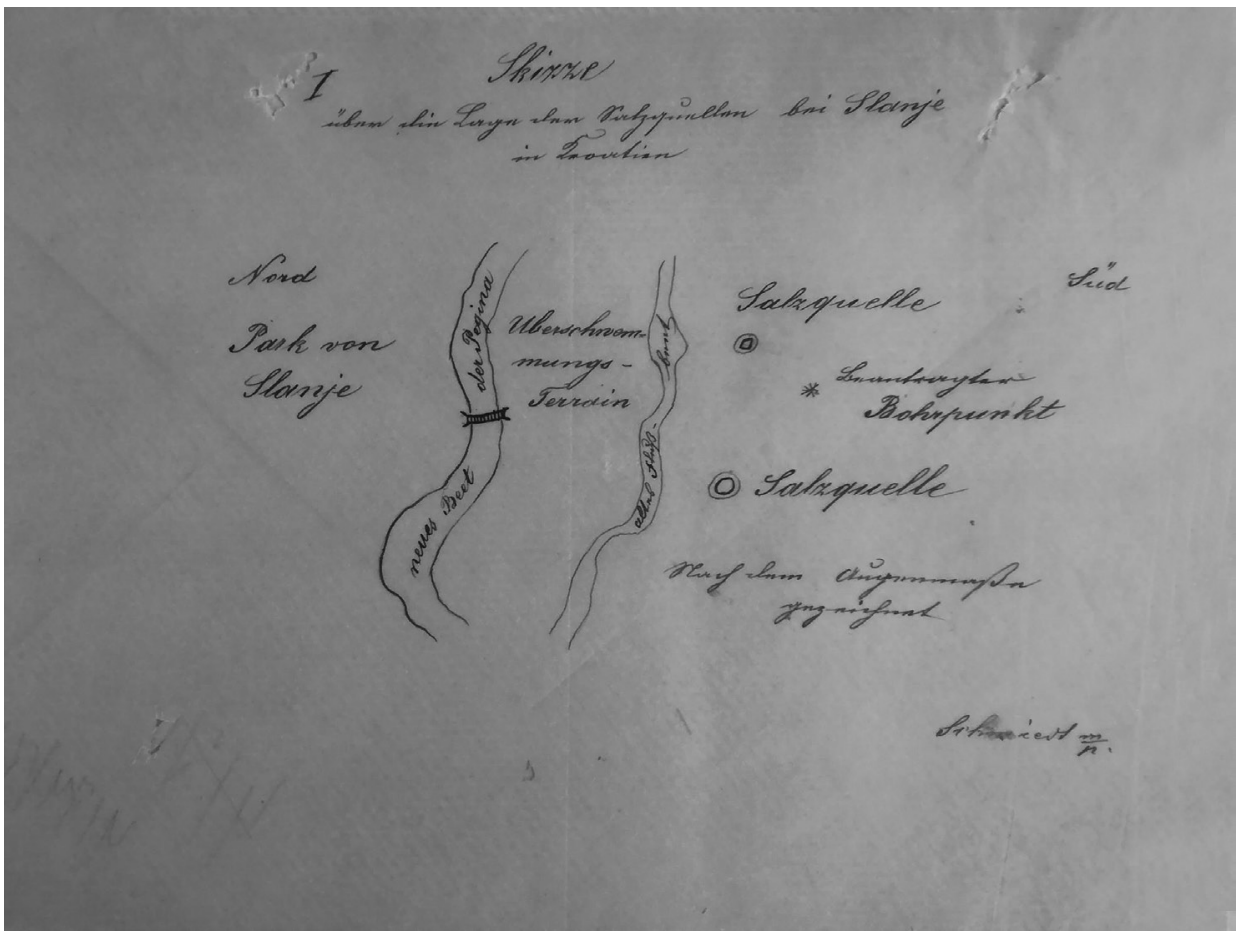

Slika 6. Skica na pausu Alojza Rikarda Schmiedta za izvore slane vode kod Slanja HR-HDA-79; sv. 20., 10853/1870-4174/1871

Na prvi pogled može se uočiti kako je skicu Alojz Rikard Schmiedt nacrtao rukom i zapisao na njemačkom jeziku na tankom pausu dimenzija 24 x 18,5 cm crnom tintom, vrlo vjerojatno na originalnoj poziciji lokaliteta slane vode prilikom radova bušenja terena. Karta u gornjem dijelu sadrži naslov "I Skizze über die Lage der Salzquellen bei Slanje in Varazdin" u prijevodu „I Skica s položajem izvora slane vode kod Slanja i Varaždina."

vonsko-dalmatinske zemaljske vlade, odjel za unutarnje poslove u Hrvatskom državnom arhivu u Zagrebu nalazi se i druga vrlo zanimljiva povijesna dokumentacija vezana za pitanje zanimljivog lokaliteta Radoboj, (op. a.). 


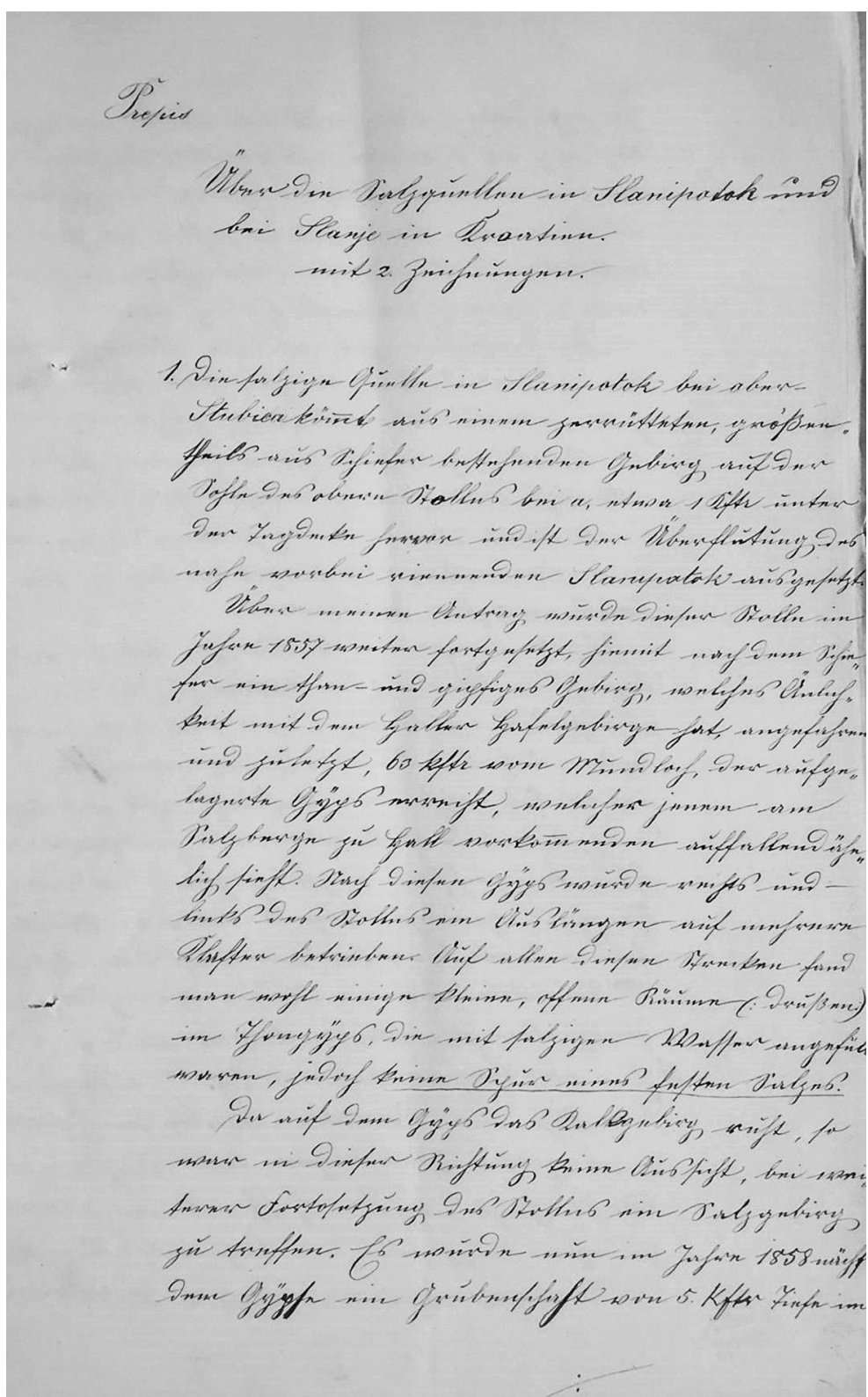

Slika 7. Prva stranica stručnog izvješća Alojza Rikarda Schmiedta za lokalitete soli Slanog potoka kod Stubice i izvore slane vode kod Slanja iz 1871. godine HR-HDA-79; sv. 20., 10853/1870-4174/187 
Autor je kartu potpisao ručno sa Schmiedt s vrlo zanimljivom opaskom m.p. u značenju "manu propria“ - „vlastoručno“. Schmiedtova karta vrlo detaljno daje prikaz starog i novog korita rijeke Bednje s prikazom pozicije poplavnog područja između dva korita, ali isto tako skica daje i prikaz novog izgrađenog mosta na koritu rijeke Bednje. Autor je osim toga vrlo točno naznačio položaj dva slanca s dvije kružne oznake kao i zvjezdicom točan položaj na jugu gdje je bilo izvršeno bušenje zemljanih slojeva za potrebe istraživanja terena, dok je na sjevernom položaju jasno upisao poziciju prostiranja tadašnjeg parka u Slanju. Skica je napravljena bez mjerenja na terenu i uvezena je u spis zemaljske vlade odjela za unutarnje poslove u Zagrebu. Uz ove dvije vrlo vrijedne skice navedenog autora tijekom čitanja izvora otkriveno je originalno rukom pisano geografsko - geološko izvješće za navedene radove na lokalitetu Slani potok kod Stubice i izvore slane vode kod sela Slanje. Schmiedt je izvješće naslovio pod naslovom "Über die Salzquellen in Slani potok und bei Slanje in Varazdin mit zwei Zeichnungen" u prijevodu „O izvorima soli u Slanom potoku i kod Slanja kod Varaždina s dva crteža“. Izvješće je potpisao Schmiedt i datirao s 26. ožujka 1871. godine. U tekstu donosimo prikaz prve stanice navedenog izvješća na njemačkom jeziku. ${ }^{22}$

Sudeći prema svim gore iznesenim podacima može se zaključiti kako na kraju ipak nije došlo do priželjkivane eksploatacije soli iz slane vode dva izvora tzv. „Slan$c a^{\prime \prime}$ kod Slanja. Za potrebe istraživanja lokaliteta Slanje tijekom zadnjih nekoliko godina izvedeno je u više navrata fotografiranje spomenute zone te stoga u nastavku članka donosimo nekoliko fotografija i zračnih snimaka koje najbolje prikazuju sadašnje stanje uz rijeku Bednju s postojećim selom i izvorima vode.

22 Tekst izvješća Schmiedta koji bi sigurno dao vrijedne podatke ostao je zbog nečitkog rukopisa nejasan tijekom pisanja ovog članka, (op. a.).

23 Stanovnici sela Slanje i okolnog područja tijekom terenskog istraživanja izjavili su da su navedeni izvori slane vode bili korišteni iza Il. svjetskog rata za opskrbu domaćih životinja solju, kao i za potrebe kućanstva. Neki su naveli da voda sadrži tzv. gorku sol koja je efikasnija od ricinusovog ulja, (op. a.). 
SPOMENKA VLAHOVIĆ : O izvorima slane vode kod Stubice i Slanja prema arhivskim podacima...

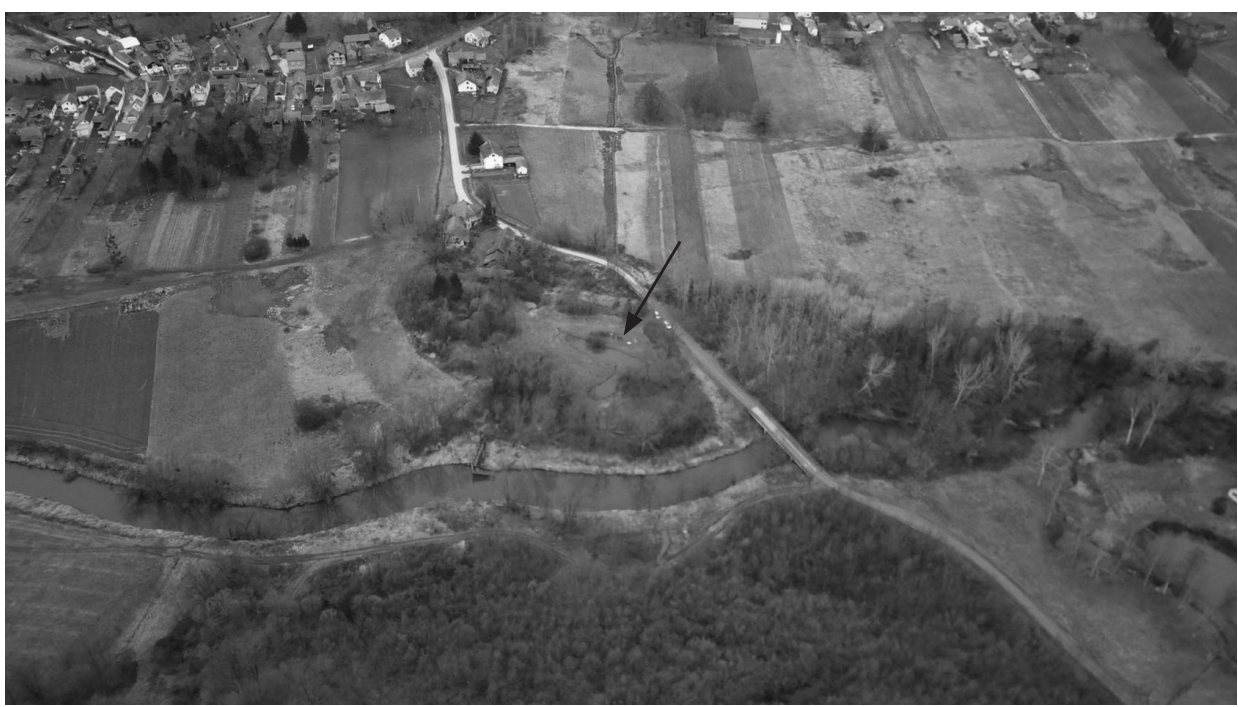

Slika 8. Pogled iz zraka na selo Slanje s rijekom Bednjom i izvorima slane vode ožujak 2021., foto: Zoran Bunić

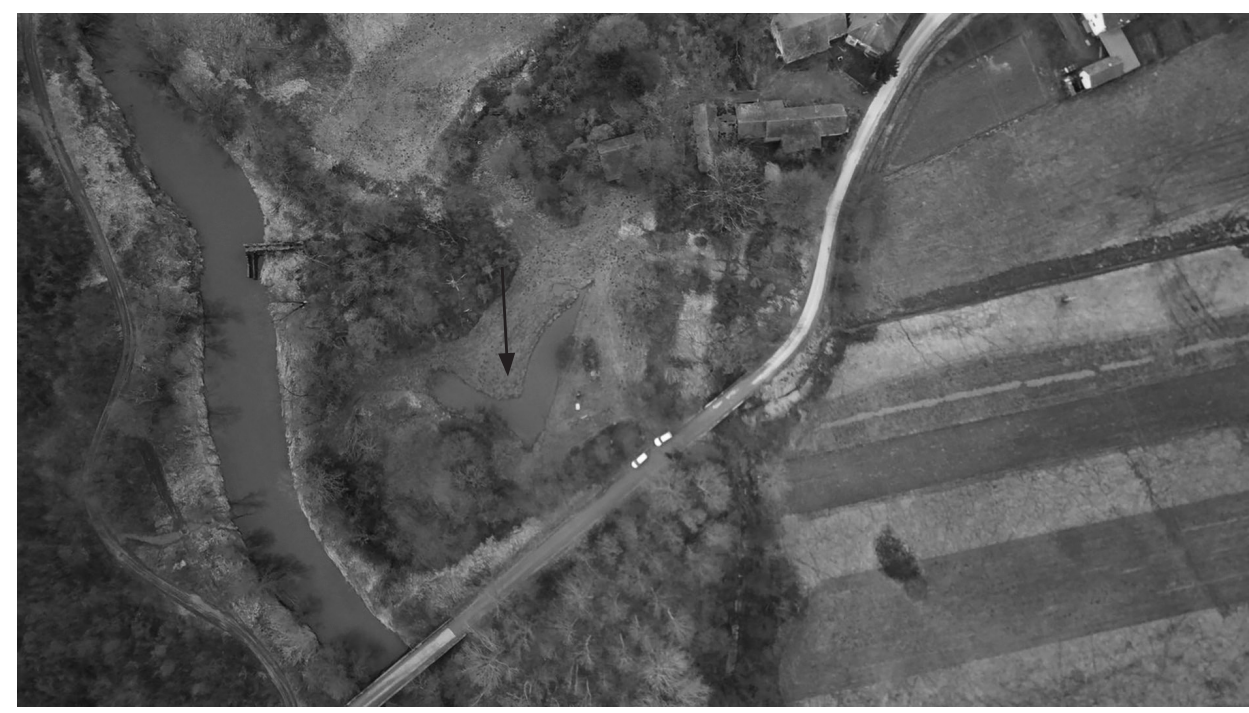

Slika 9. Pogled na izvore slane vode uz rijeku Bednju kod sela Slanje ožujak 2021., foto: Zoran Bunić 


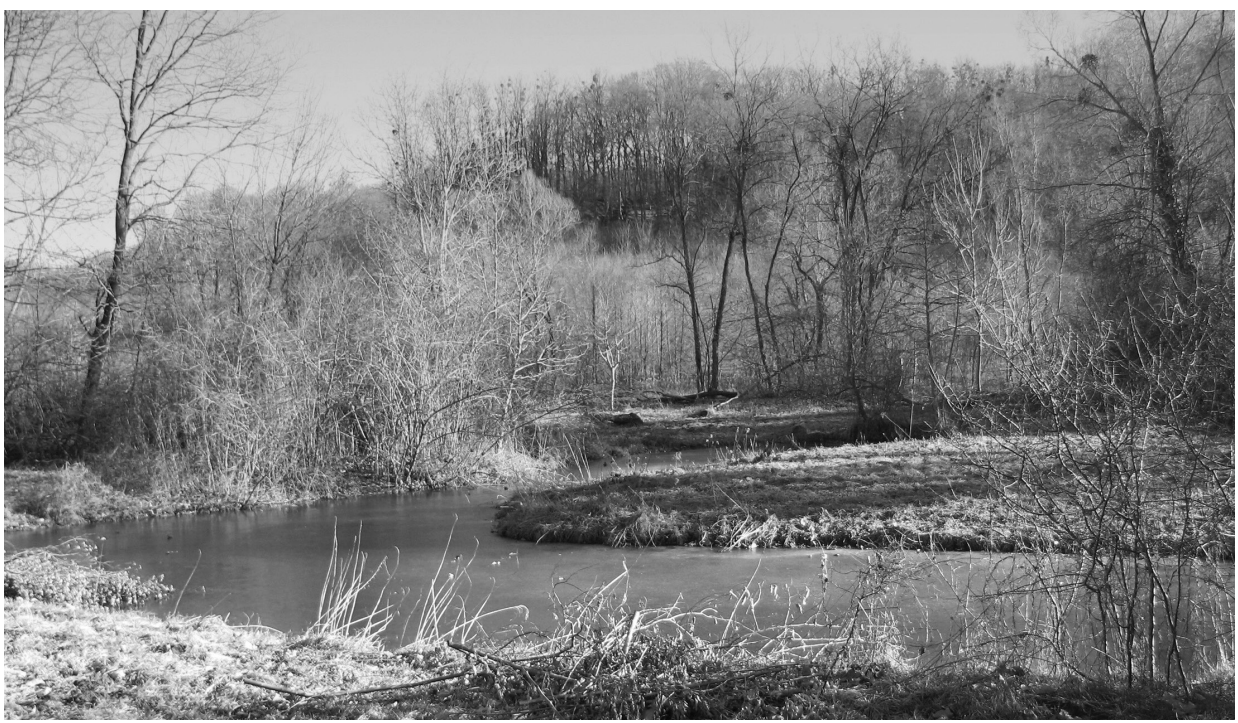

Slika 10. Pogled na izvore slane vode kod Slanja, studeni 2019., foto: Spomenka Vlahović

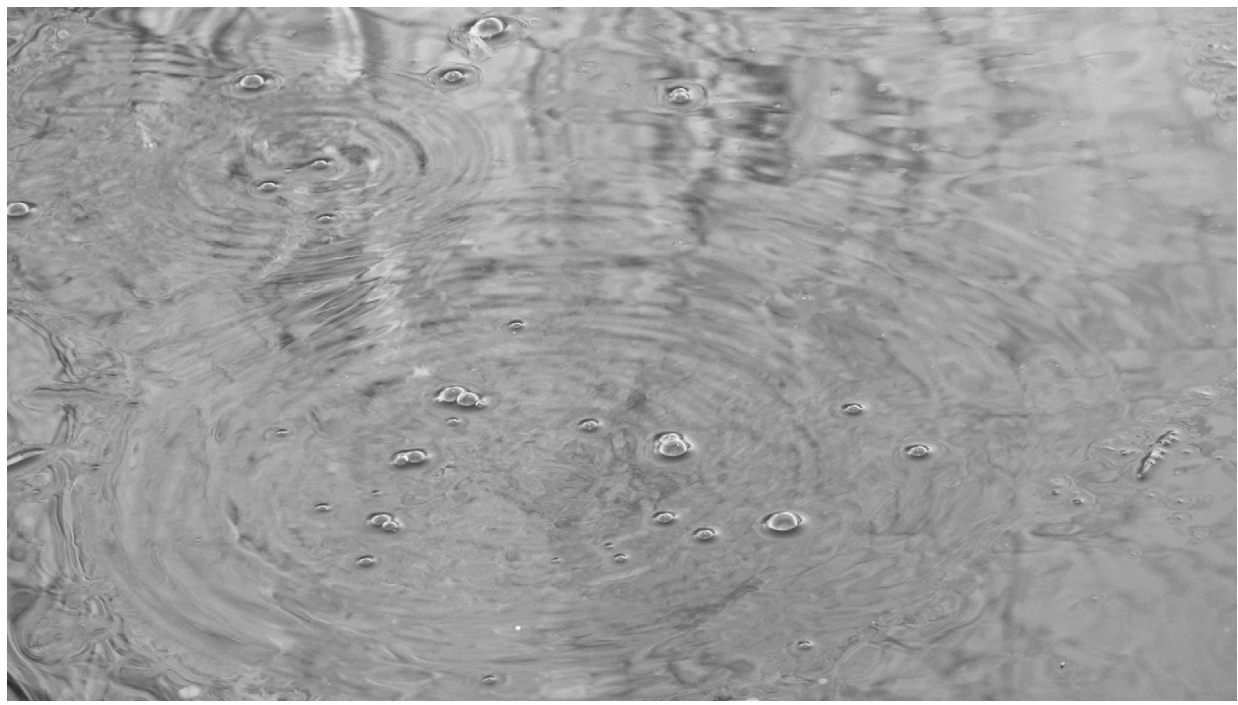

Slika 11. Detalj s pojavom mjehurića na površini izvora slane vode kod sela Slanje studeni 2019., foto: Spomenka Vlahović 
SPOMENKA VLAHOVIĆ : O izvorima slane vode kod Stubice i Slanja prema arhivskim podacima...

\section{REZULTATI NAJNOVIJIH GEOLOŠKIH, HIDROKEMIJSKIH I ARHEOLOŠKIH ISTRAŽIVANJA VEZANI UZ IZVORE SLANIH VODA}

Na kraju iznosimo još jedno vrlo zanimljivo mišljenje, a moguće i direktnu vezu koju bi trebalo znanstveno proučiti između dva značajna povijesna i geološka lokaliteta izvora vode na teritoriju Varaždinske županije a to su izvori slane vode tzv. Slancah kod Slanja i izvor geotermalne ljekovite vode Varaždinskih Toplica. U najnovijoj rudarsko-geološkoj studiji za navedeno područje izdanoj 2015. za vodu Varaždinskih Toplica stoji; „,... da se izvor vode nalazi u tjemenu antiklinale čiju jezgru čine trijaski dolomiti. Sabirno područje ovih voda predstavlja područje Ivanščice, otkud podzemnim putovima dolaze do Varaždinskih Toplica, gdje se zbog tlaka uzdižu prema površini. Termalna voda se ovdje koristila još u doba Rimljana, o čemu svjedoče arheološki spomenici iz 1. st. n.e. ... Temperatura vode je oko $56{ }^{\circ} \mathrm{C}$, a prema hidrokemijskim značajkama voda je Ca-Mg-HCO3 SO4 tipa. Ukupna mineralizacija je 1017 mg/l, te je voda određena kao hipertermalna i termomineralna. Kapacitet izvora (kaptaže) iznosi oko $35 \mathrm{l} / \mathrm{sec}$, a u bušotini je bila izdašnost $100 \mathrm{l} / \mathrm{sec}$. Šimunić (1988) je na temelju visokih količina istaložene sedre $(30-40 \mathrm{~m})$ te fosilnih ostataka nađenih u sedrenoj spilji pretpostavio da izvori u Varaždinskim Toplicama spadaju među najstarija termalna vrela u panonskom dijelu Republike Hrvatske. Kasnije su Horvatinčić i dr. (1990) pokušali na temelju izotopa 14 C utvrditi starost termalne vode u Varaždinskim Toplicama. Oni usprkos brojnih analiza, u sedri i u termalnoj vodi nisu pronašli izotop 14 C. To bi se moglo tumačiti na različite načine, ali najvjerojatnije je da je termalna voda koja danas izvire u Varaždinskim Toplicama starija od 40000 godina. Najvjerojatnije je "ušla" u podzemlje tijekom posljednjeg virmskog interglacijala. Za rješavanje podrijetla termalne vode važna je i spoznaja navedenih autora da u staroj sedri ima puno više soli nego u današnjoj termalnoj vodi. Prema tome, je $i$ „starija" termalna voda morala imati više soli nego današnja. Znači da je u prvo vrijeme na termalnim izvorima u Varaždinskim Toplicama prevladavala "fosilna voda" koja je "ušla" u podzemlje prilikom marinske transgresije u gornjem badenu ili je zaostala u sedimentima Panonskog mora. Prema tome, starost jednog dijela termalne vode može biti oko 14,5 milijuna godina. Nakon što su početkom pleistocena erozijom otvoreni dolomiti na padinama Kalnika i Ivanščice, stvoreni su uvjeti za akumulaciju oborinskih voda. Ona je mogla ući u cirkulaciju po „uklještenom vodonosniku" tek kada je iz njega istekla starija voda (Šimunuć i Hećimović). Zbog toga je u Varaždinskim Toplicama prvo izvirala jako slana voda („naftna voda“) a sada izvire miješana voda. Taj proces još uvijek nije potpuno završen jer termalni 
izvor u Varaždinskim Toplicama ima dvostruko veću mineralizaciju od svih Toplica u Hrvatskom zagorju".24

S obzirom na gore iznesene geološke podatke svakako bi bilo zanimljivo vidjeti u budućnosti novu geološku komparativnu analizu voda spomenuta dva lokaliteta.

Kako oba lokaliteta predstavljaju izuzetno važno javno dobro Republike Hrvatske od 2018. na poziv autorice teksta grupa istraživača na terenu je proširena geolozima iz Republike Slovenije na čelu s dr. Jani Mulecom, dr. Andreea Oarga-Mulec i dr. Vesnom Zalar-Serjun s Instituta za raziskovanje krasa iz Postojne koji su na lokalitetu izvora slane vode Slanje tijekom terenskog istraživanja iz prikupljenih geoloških uzoraka do sada uspjeli potvrditi kako se radi o izuzetno alkalnoj vodi s visokom koncentracijom soli. Grupi geologa se tijekom 2019. kao hrvatski istraživač priključila i dr. Sanja Kapelj iz Geotehničkog fakulteta Sveučilišta u Zagrebu. Treba pričekati završetak svih geoloških analiza koje su u tijeku kako bi se dobila potpuna i nova geološka slika za zanimljiv lokalitet Slanje nedaleko Varaždinskih Toplica. Kako je poznato iz raznih provedenih studija korištenje alkalnih voda danas je u porastu u svijetu i u Hrvatskoj. Nutricionisti u svojim preporukama često preporučuju ispijanje alkalne vode s ciljem uspostave $\mathrm{pH}$ ravnoteže u ljudskom organizmu. Navode kako sprečava stvaranje kamenca u bubrezima i razvoj niza spektra bolesti koje su povezane sa zdravljem bubrega i zadržavanjem otrova u organizmu. Novija provedena istraživanja potvrđuju da takva voda može pomoći u prevenciji nekih vrsta raka s obzirom na podatak da se stanice raka razvijaju i rastu u kiseloj sredini, a novija potvrđuju da ne mogu preživjeti u alkalnoj vodi.

Zanimljiva studija objavljena 2001. prezentirana u Shanghaiu „Journal of Protective Medicine“ pokazala je da ispijanje alkalne vode kroz 3 do 6 mjeseci doprinosi snižavanju razine kolesterola, glukoze u krvi i krvnog tlaka kod pacijenata. Godine 2010. objavljeno je istraživanje u "The Journal of International Society of Sports Medicine" koje je pokazalo da ispitanici koji su pili alkalnu vodu postigli vidno poboljšanje acido-bazne ravnoteže i status hidratacije u organizmu u odnosu na one koji su pili vodu iz slavine. Druga studija objavljena u "Annals of Otology, Rhinology \& Laryngology" iz 2012. potvrdila je da voda s pH 8,8 učinkovito neutralizira želučane kiseline i pepsin, što je čini korisnom kod liječenja želučanog refluksa. Zanimljivo mišljenje vezano uz temu daju i njemački arheolozi koji smatraju kako su na teritoriju današnje Njemačke u predrimsko vrijeme bile korištene posebne kupališne kure i metode ispijanja slane vode, a otkrili su

24 Rudarsko-geološkastudija Varaždinskežupanije, Hrvatskigeološkiinstitut, Zagreb, 2015., str. 275276. 
i dokaze o ljekovitosti slane vode u liječenju raznih kožnih bolesti. ${ }^{25} J$ dan od najzanimljivijih arheoloških lokaliteta danas Lunca - Vănatori, okrug Neamt vezan je uz otkriće više od 200 izvora slane vode koji su otkriveni u moldavsko predkarpatskom području u Rumunjskoj. Otkriveni su na arheološkom lokalitetu koji se datira u period mlađeg kamenog doba oko 6000 - 3500 pr. Kr. Istraživanja su između ostalog potvrdila najstarije dosad poznate tragove dobivanja soli iz slane vode na području Europe. U sklopu francusko - rumunjskog istraživačkog projekta od 2003. - 2010. otkriveno je uz mnoštvo arheoloških podataka i vrlo duga tradicija korištenja soli dobivene u postupku iskuhavanja slane vode, a istu koriste stanovnici područja i danas za potrebe kućanstva, u ovčarstvu kao i u proizvodnji lokalnog sira. Pretpostavka istraživača je, kako su prvi ljudi u doba prapovijesti vrlo vjerojatno koristili samo slanu vodu, a kasnije i nus proizvod tj. čistu kristaliziranu sol koja je nastala prirodnim putem prilikom procesa isparavanja uslijed utjecaja sunčevih zraka i topline. ${ }^{26}$

\section{ZAKLJUČAK}

Možda bi se i kod opisana dva hrvatska lokaliteta Slanog Potoka i Slanja također moglo raditi o vrlo dugoj tradiciji korištenja slane vode od prapovijesti preko antike pa sve do novog doba za što postoje zanimljive razne arheološke indicije i potvrđeni lokaliteti u samoj blizini koje bi trebalo detaljnije u budućnosti istražiti u odnosu upravo na resurse izvora slanih voda. Svi izneseni podaci u ovom radu daju vrlo dobre temelje za buduću novu kulturno - turističku prezentaciju, popularizaciju i interpretaciju zaboravljenih izvora slane vode kod Slanja sa zadatkom budućeg očuvanja prirodne i kulturne baštine Varaždinske županije.

25 Hans-Henning WALTER, Der salzige Jungbrunnen, Die Geschichte der deutschen Solebäder-Soleheilader, Drei Birken Verlag, 2006.

26 Marius ALXIANU, Olivier WELLER, Robin BRIGAND, Roxana Gebriela CURCĂ, Annäherung an eine unsichtbare Vergangenheit: Etnoarcheologische Forschungen den Salzwasserquellen der moldanischen Vorkarpaten (Rumäniens), u: Studia antiqua et archaeologia XX, 2014., str. 7-3. 


\section{LITERATURA}

1/ Anton EDLER V. HARTIG, Physisch-chemische Untersuchung der Mineralquellen von Stubitza in Kroatien, Agram 1820.

2/ August NEILREICH, Die Vegetationsverhältnisse von Croatien, K. und K. zoologisch-botanische Gesellschaft, Wien, 1868.

3/ Antun KANCIJAN, Traganje za podrijetlom imena sela ludbreške Podravine, u „Podravski zbornik“, No. 10., Tisak SOUR „Podravka“, Koprivnička tiskara, nakladnik Muzej Koprivnica, Koprivnica, 1984.

4/ Berislav ŠEBEČIĆ, Rudarstvo i talioničarstvo većeg dijela tadašnje Hrvatske na svjetskim izložbama u Beču 1873. i u Budimpešti 1885., u „Rudarsko geološki - naftni zbornik", br. 12., Zagreb, 2000.

5/ Fran TUĆAN, Mineralogija: Specijalna mineralogija, Školska knjiga, Zagreb, 1957.

6/ Hrvoje PETRIĆ, O nekim naseljima u porječju rijeke Bednje tijekom srednjeg i početkom novoga vijeka, u časopisu KAJ, XLIII, br. 3., Zagreb, 2010.

7/ Hrvoje PETRIĆ, Pogranična društva i okoliš - Varaždinski generalat i Križevačka županija u 17. stoljeću, izdavačka kuća Meridijani, Samobor, 2012.

8/ Hans - Henning WALTER, Die Geschichte der deutschen Solebäder - SoleheiIbäder, Drei Birken Verlag, 2006.

9/ Ludvig v. VUKOTINOVIC, Geognostische Skizze vom Warasdiner Teplitz in Croatien, u „Jahrbuch der Geologischen Reichsanstalt", 3/4, Wien, 1852.

10/ Ludvig v. VUKOTINOVIC, Flora croatica, Academiae scientiarum et artium slavorum meridionalium, Zagreb, 1869.

11/ L. W. BEREZIN, Kroatien, Slavonien, Dalmatien und das Militärgrenzland, Selbstverlag dr. J. P. Jordan, Wien, 1880.

12/ Marius ALEXIANU, Olivier WELLER, Robin BRIGAND, Roxana Gabriela CUR$C \breve{A}$, Annäherung an eine unsichtbare Vergangenheit: Etnoarchäologische Forschungen den Salzwasserquellen der moldanischen Vorkarpaten (Rumänien), u ,Studia antiqua et archeologia, XX, 2014.

13/ Mijo LONČARIĆ, Kajkavština u ranim podravskim toponimima, u časopis "Folia onomastica Croatica", br. 12-13, Zagreb, 2003-2004.

14/ Otto HÜBNER, Nachrichten aus dem Gebiet Staats- und Volkswirschaft, nebst-Beilage Vericherungs-Zeitung, drugi svezak, tisak Brandis, Berlin, 1853.

15/ Peter MATKOVIĆ, Kroatien-slavonien nach seinen physischen und geistigen Verhältnissen - Denkschrift zur Wiener Weltaustellung 1873., Acktien Buchdruckerei, Agram, 1874. 
16/ Vjekoslav KLAIĆ, Poučna knjižica, Matica Hrvatska, knjiga 1., Prirodni zemljopis Hrvatske, knjižara Albrechta Fiedlera, Zagreb, 1878.

17/ Živko VUKASOVIĆ, Pabirci za zemljoslovlje Dalmacije, Hrvatske i Slavonije, Zagreb, 1869.

18/ Dnevnik sabora trojedne kraljevine Dalmacije, Hrvatske i Slavonije, god. 1868-1871., Tiskara Narodne novine, Zagreb, e- knjiga https://books.google.hr.

19/ Registar arheoloških nalaza i nalazišta sjevero-zapadne Hrvatske, Muzejsko društvo sjevero-zapadne Hrvatske, sekcija arheologa i preparatora, tisak Colorprint Bjelovar, Varaždin, 1990.

20/ Rudarsko - geološka studija Varaždinske županije, Hrvatski geološki institut, Zagreb, 2015.

21/ Hrvatska na tajnim zemljovidima 18. i 19. stoljeća, Zagreb, 1990-2000.

22/ Hrvatski državni arhiv u Zagrebu - signatura fonda/zbirke: HR - HDA -79 svezak 20, 10853/170-4174/1871, Kraljevsko rudarsko satništvo (razdoblje 1859-1918.), Zemaljska vlada - Odjel za unutarnje poslove, nacrti, planovi i karte.

\section{SUMMARY}

\section{ABOUT THE SAURCES OF SALT WATER NEAR STUBICA AND SLANJE ACCOR- DING TO ARCHIVAL AND FIELD DATA RESEARCH}

The paper presents new data on the discovery of historical documentation important for understanding the salt water source near Slani potok near Stubica and two salt water sources near the village of Slanje near Varaždinske Toplice. As salt has played a very important role in human and animal nutrition since time immemorial and in various epochs of human civilization has had a great influence in various cultures around the world. In chronological order, a cross-section of events related to the research of the water source Slanja, the so-called Slanca, and for the first time historical very valuable sketches of the mentioned localities made by Alojz Rikard Schmiedt are shown. During the research conducted in 2018, when the aforementioned archival documentation was discovered in the Croatian State Archives in Zagreb, it was the new basis for the conducted field research at the aforementioned Slanje site. Given that over time these water sources have fallen into oblivion and are now in a state of disrepair, they are no longer used, this 
paper therefore has the main goal to draw the attention of experts to their value and importance in the need for new interpretation, valorization and popularization of special branch of geological heritage of the Republic of Croatia which is today located in the area of Varaždin County. The paper also presents other valuable historical data for this area, as well as other new scientific knowledge gained through research.

Key Words: geology; balneology; archeology; salt water sources; rock salt. 